\title{
Karabük ilinde çocuk hastalarda hepatit A, B ve C seroprevalansı
}

\author{
Seroprevalence of HAV, HBV, and HCV in Pediatric Patients in Karabuk Province
}

\author{
Erkan DOĞAN¹, Eylem SEVINÇ², Cüneyt KURU³ \\ Karabük Üniversitesi Tıp Fakültesi, ${ }^{1}$ Çocuk Sağlığı ve Hastalıkları Ana Dalı, ${ }^{2}$ Çocuk Gastroenteroloji, ${ }^{3}$ Mikrobiyoloji, Karabük
}

Giriş ve Amaç: Bu çalışmada Karabük ilindeki çocuklarda Hepatit A, B ve $C$ seroprevalansını saptamak amaçlandı. Gereç ve Yöntem: Kesitsel tipteki bu çalışma, Ocak 2015 - Aralık 2016 tarihleri arasında çocuk polikliniğimize farklı şikayetlerle başvurmuş 0-18 yaş grubu çocuklarda gerçekleştirildi. Çalışmaya alınan çocuklar 0-1 yaş, 2-6 yaş ve 7-18 yaş olmak üzere 3 gruba ayrıldı. Çocuklardan alınan kan örneklerinde Anti-HAV IgM, Anti-HAV IgG, HbsAg, Anti-Hbs ve Anti-HCV değerleri Enzyme-Linked Immunosorbend Assay (ELISA) yöntemi ile test edildi. Bulgular: Çalışmaya alınan 2024 hastanın 785'i $(\% 38,8)$ kız, 1239'u $(\% 66,2)$ erkekti. Hastaların yaşları 0 ile 18 arasında olup, yaş ortalaması 10,24 $\pm 4,71$ yıl idi. Anti-HAV IgM pozitifliği \%6,5 ve Anti-HAV IgG pozitifliği \%28 olarak saptandı. Hastaların $\mathrm{HbsAg}$, Anti-Hbs ve Anti-HCV seropozitiflikleri; sırasıly $\% 0,2, \% 61,1$ ve $\% 0,1$ olarak saptandı. Sonuç: ilimiz ve çevresinde daha önce hepatit $A, B$ ve $C$ seropozitifliğini gösteren çalışma yoktur. Ülkemizde hepatit A enfeksiyonunun serolojik prevalansı coğrafik bölgeler arasında değişkenlik göstermektedir. Ilimizdeki düşük tespit ettiğimiz hepatit A seroprevalansı su ve yiyecek hijyeninin iyi kontrol edilmesiyle ilişkilendirilebilir. Çalışmamızdaki hepatit $B$ ve hepatit C seroprevalans oranları, ülkemizdeki genel nüfus oranlarılya uyumludur.

Anahtar kelimeler: Çocuk, HAV, HBV, HCV, Seroprevalans.

\section{GíRiş}

Hepatit A virüsü (HAV) çocuk çağının en sık görülen viral hepatit etkenidir. Dünya genelinde her yıl yaklaşık 1.5 milyon yeni vaka olarak bildirilen hepatit A virüsü özelikle gelişmekte olan ülkelerde endemiktir. Bulaşma çoğunlukla fekal oral yolla, kontamine gıda ve sular ile olmaktadır. Çocuklarda hastalık kronikleşme olmaksızın iyi prognoza sahiptir. En korkulan komplikasyonu akut karaciğer yetmezliğidir $(1,2)$.

Hepatit B virüsü (HBV) ve hepatit C virüsü (HCV) enfeksiyonları, asemptomatik enfeksiyondan siroza ve hepatoselüler karsinomaya kadar geniş klinik spektrumda olan önemli halk sağlığı problemleridir (3). HBV prevalansı bölgeden bölgeye değişir. HBV'nin yüksek oranda endemik olduğu ülkelerde (Afrika ve Asya'nın bir bölümünde), hepatit B yüzey antijeni (HBsAg) seroprevalansı $\geq \%$, iken
Background and Aims: In this study, we aimed to investigate hepatitis A, B, and C seroprevalence in children. Materials and Methods: This cross-sectional study was carried out between January 2015 and December 2016 in children aged 0-18 years who applied for routine child examination to our pediatric clinic. The children were divided into 3 groups: 0-1 years, 2-6 years, and 7-18 years. Blood samples were taken from children, and Anti-HAV IgM, Anti-HAV IgG, HbsAg, Anti-Hbs, and Anti-HCV were determined in each sample using enzyme-linked immunosorbent assay method. Results: A total of 2024 patients were enrolled in the study, out of which 785 (38.8\%) were women and 1239 (66.2\%) were men. The mean age was $10.24 \pm 4.71$ years. Anti-HAV IgM and Anti-HAV IgG were detected in $6.5 \%$ and $28 \%$ of the patients, respectively. On the other hand, $0.2 \%, 61.1 \%$, and $0.1 \%$ of patients were detected seropositive for HbsAg, Anti-Hbs, and Anti-HCV, respectively. Conclusion: There is no previous study showing hepatitis $A, B$, and $C$ seroprevalence in our province and its surrounding area. The seroprevalence rates of Hepatitis A vary geographically in the country. The low hepatitis A seroprevalence rate may be associated with the good level of food and water hygiene in the province. In our study, $\mathrm{HBV}$ and HCV seroprevalence rates are comparable to the general population.

Key words: Children, HAV, HBV, HCV, seroprevalence

Batı Avrupa ve Kuzey Amerika'da $<\% 2$ olarak bildirilmiş (4). Daha önceleri transfüzyon ile ilişkili Non-A, Non-B hepatitinin etken olarak adlandırılan HCV, küresel olarak 11 milyonu 15 yaşından küçük olmak üzere yaklaşık 115 milyon kişiyi etkilediği tahmin edilen diğer önemli bir enfeksiyöz hastalık nedenidir (5).

Ülkemizde hepatit A, B ve C seroprevalansını saptamaya yönelik çeşitli yaş grublarında bir çok çalışma yapılmasına rağmen ilimizinde içinde bulunduğu batı karadeniz bölgesinde şu ana kadar çocuklarda böyle bir çalışma yapımamıştır. Bu çalışma Karabük ilinde çocuklarda hepatit A, $B$ ve $C$ seroprevalansını belirlemek, bulduğumuz oranları ülkemizin diğer bölgelerindeki çocukluk yaş grubunda bildirilen oranlarla karşılaştırmak amacı ile yapılmıştır. 


\section{GEREÇ ve YÖNTEM}

Kesitsel tipteki bu çalışma, Ocak 2015 - Aralık 2016 tarihleri arasında Karabük Üniversitesi Eğitim ve Araştırma Hastanesi çocuk polikliniği'ne herhangi bir nedenle başvuran 0-18 yaş grubundaki 2024 çocuk hastada yapıldı. Anti-HAV IgM, Anti-HAV IgG, HbsAg, Anti-Hbs ve Anti-HCV değerleri Enzyme Linked Immunosorbend Assay (ELISA) yöntemi ile Abbott Architect ( $A B D$ ) üretici firmanın öngördüğü prosedüre göre çalışılarak belirlendi. Verilerin incelenmesi SPSS 21.0 paket programında yapıldı. Sonuçlar sayı ve yüzde olarak ifade edildi. Karşılaştırmalarda ki kare testi kullanıldı. $p<0,05$ olan değerler istatistiksel olarak anlamlı kabul edildi. Çalışma için etik kurul onayı 2017/436851 sayı no ile Karabük Eğitim ve Araştırma Hastanesi Eğitim Planlama kurulundan alındı.

\section{BULGULAR}

Çalışmaya dahil edilen 2024 çocuk olgunun $785^{\prime} i(\% 38,8)$ kız, 1239'u ( \%66,2) erkekti. Olguların yaşları 0 ile 18 arasında olup, yaş ortalaması 10,24 $\pm 4,71$ yıl idi. Anti-HAV IgM pozitifliği \%6,5 (13/200) ve Anti-HAV IgG pozitifliği \%28 (56/200) olarak saptandı. Olguların 2 tanesinde Anti-HAV IgM ve Anti-HAV IgG birlikte pozitifliği tespit edildi. Anti-HAV IgG pozitif çocukların 30 (\%53)'u erkek, 26 (\%47)'sı kızdı. Cinsiyet açısından aradaki fark istatistiksel olarak anlamlı değildi $(p>0,05)$. Çalışmaya alınan olguların \%0,2 (3/1742)'sinde HbsAg pozitifliği, \%61, 1 (742/1215)'inde AntiHbs pozitifliği saptandı. HbsAg'si pozitif olan çocukların hiçbirinde AntiHbc IgM pozitifliği bulunmamıştır. HbsAg ve Anti-Hbs birlikte pozitifliği ise sadece 1 hastada tespit edildi. AntiHCV pozitifliği olguların \%0,1 ( 1/1724) saptandı (Tablo 1). Aynı zamanda olgunun bakılan HCVRNA'sı pozitif saptandı. Çocuk hastalar 0-1, 2-6, ve 7-18 yaş gruplarına ayrıldı. Anti-HAV IgG seropozitifliği 2-6 yaş ile 7-18 yaş, AntiHbs seropozitifliği 0-1 yaş ile 7-18 yaş grubundaki çocuklar arasında istatistiksel olarak anlamlı fark bulundu ( sırasıyla $\chi 2=8,62 p=$ 0.01 ve $\chi 2=6,13 p=0.03$ ). Çocuk hastaların yaş gruplarına göre Anti-HAV IgM, Anti-HAV IgG, HbsAg, Anti-Hbs ve AntiHCV seropozitiflik oranları Tablo 2 de gösterildi.

\section{TARTIȘMA}

Yaptıgımız calışmada Karabük ilinde 0 -18 yas grubunda hepatit A seroprevalansını \%28 saptadık. Dünyada Sosyoekonomik gelişmişlik düzeyi yüksek olan ülkelerde hepatit A seroprevalansı az gelişmiş ülkelerle kıyaslandığında daha düşük olduğu görülmüştür. Bernand ve arkadaşlarının Kanada'da 8-13 yaş aralığındaki çocuklarda yaptıkları çalışmada hepatit A seroprevalansını \%27 olarak tespit etmişlerken Ahmed ve arkadaşlarının 2009 ylında 11-15 yaş aralığında Bangladeşli çocuklarda hepatit A seroprevalansını \%80,4 olarak saptamışlar $(6,7)$.

Tablo 1. Çalışmaya alınan olgularda Anti HAV IgM, Anti HAV IgG, HbsAg, AntiHbs ve AntiHCV seropozitiflik oranları.

\begin{tabular}{|c|c|c|c|c|c|c|c|c|c|c|}
\hline & \multicolumn{2}{|c|}{ Anti HAV IgM } & \multicolumn{2}{|c|}{ Anti HAV IgG } & \multicolumn{2}{|c|}{$\mathrm{HbsAg}$} & \multicolumn{2}{|c|}{ AntiHbs } & \multicolumn{2}{|c|}{ AntiHCV } \\
\hline & $\begin{array}{l}\text { Pozitif } \\
\text { n (\%) }\end{array}$ & $\begin{array}{c}\text { Negatif } \\
\text { n (\%) }\end{array}$ & $\begin{array}{l}\text { Pozitif } \\
\text { n (\%) }\end{array}$ & $\begin{array}{c}\text { Negatif } \\
\mathrm{n}(\%)\end{array}$ & $\begin{array}{l}\text { Pozitif } \\
\text { n (\%) }\end{array}$ & $\begin{array}{c}\text { Negatif } \\
\mathrm{n}(\%)\end{array}$ & $\begin{array}{l}\text { Pozitif } \\
n(\%)\end{array}$ & $\begin{array}{c}\text { Negatif } \\
\text { n (\%) }\end{array}$ & $\begin{array}{l}\text { Pozitif } \\
\text { n (\%) }\end{array}$ & $\begin{array}{c}\text { Negatif } \\
\text { n (\%) }\end{array}$ \\
\hline$\%$ & $\begin{array}{c}13 \\
(6,5)\end{array}$ & $\begin{array}{c}187 \\
(93,5)\end{array}$ & $\begin{array}{c}56 \\
(28)\end{array}$ & $\begin{array}{l}144 \\
(72)\end{array}$ & $\begin{array}{c}3 \\
(0,2)\end{array}$ & $\begin{array}{l}1744 \\
(98,8)\end{array}$ & $\begin{array}{c}742 \\
(61,1)\end{array}$ & $\begin{array}{c}473 \\
(\% 39,9)\end{array}$ & $\begin{array}{c}1 \\
(0,1)\end{array}$ & $\begin{array}{c}1723 \\
(99,9)\end{array}$ \\
\hline
\end{tabular}

Tablo 2. Çalışmaya alınan olgularda Anti HAV IgM, Anti HAV IgG, HbsAg, AntiHbs ve AntiHCV seropozitiflik oranları.

\begin{tabular}{|c|c|c|c|c|c|c|c|c|c|c|}
\hline & \multicolumn{2}{|c|}{ AntiHAV IgM } & \multicolumn{2}{|c|}{ Anti HAV IgG } & \multicolumn{2}{|c|}{$\mathrm{HbsAg}$} & \multicolumn{2}{|c|}{ AntiHbs } & \multicolumn{2}{|c|}{ AntiHCV } \\
\hline & $\begin{array}{l}\text { Pozitif } \\
n(\%)\end{array}$ & $\begin{array}{c}\text { Negatif } \\
n(\%)\end{array}$ & $\begin{array}{l}\text { Pozitif } \\
\text { n (\%) }\end{array}$ & $\begin{array}{c}\text { Negatif } \\
n(\%)\end{array}$ & $\begin{array}{l}\text { Pozitif } \\
\mathrm{n}(\%)\end{array}$ & $\begin{array}{c}\text { Negatif } \\
n(\%)\end{array}$ & $\begin{array}{l}\text { Pozitif } \\
n(\%)\end{array}$ & $\begin{array}{c}\text { Negatif } \\
\text { n (\%) }\end{array}$ & $\begin{array}{l}\text { Pozitif } \\
\text { n (\%) }\end{array}$ & $\begin{array}{c}\text { Negatif } \\
\text { n (\%) }\end{array}$ \\
\hline 0-1 yaş & - & - & - & - & $\begin{array}{c}1 \\
(4,8)\end{array}$ & $\begin{array}{c}20 \\
(95,2)\end{array}$ & $\begin{array}{l}14^{\star *} \\
(77,8)\end{array}$ & $\begin{array}{c}4 \\
(22,2)\end{array}$ & - & $\begin{array}{c}20 \\
(100)\end{array}$ \\
\hline 2-6 yaş & $\begin{array}{c}4 \\
(3,4)\end{array}$ & $\begin{array}{c}81 \\
(96,6)\end{array}$ & $\begin{array}{c}40 * \\
(66,7)\end{array}$ & $\begin{array}{c}20 \\
(33,3)\end{array}$ & - & $\begin{array}{c}404 \\
(100)\end{array}$ & $\begin{array}{c}186 \\
(71,3)\end{array}$ & $\begin{array}{c}75 \\
(28,7)\end{array}$ & - & $\begin{array}{c}386 \\
(100)\end{array}$ \\
\hline 7-18 yaş & $\begin{array}{c}9 \\
(7,8)\end{array}$ & $\begin{array}{c}106 \\
(92,1)\end{array}$ & $\begin{array}{c}16^{*} \\
(11,5)\end{array}$ & $\begin{array}{c}124 \\
(88,5)\end{array}$ & $\begin{array}{c}2 \\
(0,2)\end{array}$ & $\begin{array}{l}1320 \\
(98,8)\end{array}$ & $\begin{array}{l}542 * \star \\
(57,9)\end{array}$ & $\begin{array}{c}394 \\
(42,1)\end{array}$ & $\begin{array}{c}1 \\
(0,1)\end{array}$ & $\begin{array}{c}1317 \\
(99,9)\end{array}$ \\
\hline
\end{tabular}


Ülkemizde Yılmaz ve arkadaşlarının 2015 yılında Kars ilinde 0-18 yaş grubundaki çocuklarda yaptıkları çalışmada hepatit A seroprevalansını \%66,5, Okur ve arkadaşlarının 2011 yılında Van ilinde aynı yaş grubunda yaptıkları çalışmada hepatit A seroprevalans oranını \%69,9, Aslan ve arkadaşlarının Şanlıurfadaki çocuklarda hepatit A seroprevelansı oranını \%66,5 olarak tespit etmişlerken $(8,9,10)$; Çicek ve arkadaşlarının 2012 yılında doğu karadeniz bölgesinde olan Rize ilinde 0-17 yaş grubunda çocuklarda yaptıkları çalışmada hepatit A seroprevalansını \%29,5, Güven ve arkadaşlarının 2004 yılında İstanbul'da 0-15 yaş grubunda yaptıkları çalışmada ise hepatit A seroprevalansını \%42,1 olarak saptamışlar $(11,12)$. Ulusal literatürümüzde Batı Karadeniz bölgesinde çocuklardaki hepatit A seroprevalans oranını araştıran bir çalışmaya rastlamadığımızdan çalışmamızda bulduğumuz oranı ülkemizin farklı bölgelerinden bildirilen oranlarla kıyasladığımızda sonuçlarımızın diğer bölgelere göre düşük olduğunu tespit ettik. Çalışmamız tespit ettiğimiz düşük hepatit A seroprevalans oranı, bölgemizdeki yüksek sosyoekonomik gelişmişlik düzeyine ve sanitasyon koşullarının yeterli olmasıyla ilişkilendirilebilir.

Yaptığımız çalışmada yaş alt gruplarına göre hepatit A seroprevalansı oranı 2-6 yaş aralığındaki çocuklar için \%66,7, 7-18 yaş aralığındaki çocuklarda ise \%11,5 olarak saptadık. Güven ve arkadaşlarının çalışmasında 2-6 yaş arasındaki çocuklarda hepatit A seroprevalansı \%33,5, 7-15 yaş arasında ise \%47.5 olarak bildirmişken Aşcı ve arkadaşlarının Afyon'da yaptığı çalışmada ise oranı 3-4 yaş arasındaki çocuklarda \%44,2 5-6 yaş arasında \%56,3, 11-18 yaş arasında \%65,2'ye yükseldiğini saptamışlar $(12,13)$. Çalışmamızda 7-18 yaş arasındaki çocuklarda bulduğumuz sonuçların gerek Aşçı gerekse Güven ve arkadaşlarının tespit ettikleri oranlardan daha düşük bulunmasının sebebi ise; bu yaş grubunda çalışmaya alınan vaka sayısının az olmasından kaynaklandığı düşünüldü.

Şanlıurfa'da 1997 yılında Kösecik ve arkadaşlarının çocuklarda yaptıkları bir çalışmada HbsAg pozitifliğini \%12,5 olarak bildirmişlerken 2002 yılında yine Şanlıurfa'da Zeyrek ve arkadaşlarının çocuklarda yaptıkları bir çalışmada HbsAg pozitifliğinin \%2, AntiHbs pozitifliğini \%31 olarak saptamışlardır $(14,15)$. Her 2 çalışmanın sonuçları karşılaştırıldığında Sağlık Bakanlığı tarafından 1998 yılından itibaren hepatit B aşısının çocuklar için zorunlu aşı takvimine dahil edilmesiyle çocuklarda HbsAg pozitifliğinde belirgin bir düşme AntiHbs seropozitifliğinde belirgin bir artış gözlenmesi rutin hepatit B aşılamasının etkili bir şekilde uygulandığını göstermektedir.
Kaya ve arkadaşlarının 2011 yılında Van ilinde 0-18 yaş aralığındaki çocuklarda yaptıkları çalışmada HbsAg pozitifliği \%0,2, AntiHbs pozitifliğini \%72,5 olarak saptamışlarken, 2017 yılında Altan ve arkadaşlarının aynı yaş grubundaki çocuklarda yaptıkları çalışmada HbsAg pozitifliğini \%0,8, AntiHbs pozitifliğini ise \%75,3 olarak bildirmişler $(16,17)$. Çicek ve arkadaşlarının Rize'de aynı yaş grubundaki çocuklarda yaptıkları çalışmada HbsAg pozitifliğini \%2,4, AntiHbs pozitifliğini ise \%79 olarak bildirmişler (11). Bizim çalışmamızda 0-18 yaş aralığındaki çocuklarda HbsAg pozitifliğini \% 0,2, AntiHbs seropozitifliği ise \%61,1 olarak bulundu. Yaş alt gruplarına göre ise çocuklarda AntiHbs seroprevalansını 0-1 yaş arasında $\% 77,8,2-6$ yaş arasında \%71,3, 7-18 yaş arasında \%57,9 olarak saptadık. Karabük Halk Sağlığı Müdürlüğünün verilerine göre hepatit B aşılanma oranı ilimizde 2000'li yıllarda \%79 iken 2017 yılının ilk 6 ayında \% 99 olarak bildirilmiş olmasına rağmen AntiHbs pozitifliği oranlarımız her üç çalışmada bildirilen oranlardan daha düşük çıkması hepatit B aşılaması yapılan çocuklarda yeterli antikor yanıtı oluşup oluşmadığının kontrol edilmesi gerekliliğini ortaya koymuştur.

Çocuklarda hepatit C seroprevalansı Amerika Birleşik Devletleri ve Avrupa gibi gelişmiş ülkelerde \%0.05-0.36, az gelişmiş ve gelişmekte olan ülkelerde \%1.8-5.8 arasında değişmektedir (18). Ülkemizde ise kısıtlı sayıda yapılan çalışmada hepatit C seroprevalansı \%0,0-1,4 olarak bildirilmiştir (19). Çalışmamızda Anti-HCV pozitifliği \%0,1 olarak saptadık. Zeyrek ve arkadaşlarının Şanlıurfa'da çocuklarda yaptıkları çalışmada olguların hiçbirinde Anti-HCV pozitifliği tespit etmemişken Ataberk ve arkadaşlarının Konya yöresinde 2000 yılında çocuklarda yaptıkları çalışmada Anti-HCV seroprevalansını \%0,21, Çiçek ve arkadaşlarının Rize'de yaptıkları çalışmada ise Anti-HCV seroprevalansını \%0,6 olarak saptamışlar $(11,15,20)$. Eke ve arkadaşlarının 2016 yılında Nijerya'da okul çağı çocuklarda yaptıkları çalışmada Anti-HCV seroprevalansını \%1 olarak bildirmişler (5). Bulduğumuz bu sonuç gerek ülkemizden gerekse yurtdışından yapılan çalışmaların sonuçlarıyla benzerlik göstermektedir.

Sonuç olarak aşılanma oranı yüksek olan ilimizde çocuklarda Anti-HAV ve AntiHbs seropozitifliği, ülkemizden bildirilen çalışmaların sonuçlarından düşük olarak saptanması aşılama yapılan çocuklarda yeterli antikor yanıtı oluşup oluşmadığının kontrol edilmesi gerekliliğini ortaya koymuştur. HCV seroprevalansı ise ülkemizdeki genel nüfus oranıyla orantılıdır. 


\section{KAYNAKLAR}

1. Verma YS, Rajput SS, Rajput N. Seroprevalence of hepatitis A virus infection in children. Sch J App Med Sci 2014;2:1144-7.

2. Kazemi SA, Mahram M, Koosha A, et al. Seroprevalence of hepatitis $A$ in 7-10 year-old children. Iran J Ped 2007;3:47-51.

3. Villar LM, Amado LA, de Almeida AJ, et al. Low prevalence of hepatitis $B$ and $C$ virus markers among children and adolescents. Biomed Res Int. 2014;2014:324638.

4. De Paschale M, Manco MT, Belvisi L, et al. Prevalence of markers of hepatitis B virus infection or vaccination in HBsAg-negative subjects. Blood Transfus 2012;10:344-50.

5. Eke CB, Ogbodo SO, Ukoha OM. Seroprevalence and correlates of hepatitis $C$ virus infection in secondary school children in Enugu, Nigeria. Ann Med Health Sci Res 2016;6:156-61.

6. Bernard D, Gaston DS, Jan O et al. Nationwide Canadian study of hepatitis $A$ antibody prevalence among children eight to thirteen years old. Pediatr Infect Dis J 2005;24:514-9.

7. Ahmed M, Munshi SU, Nessa A, et al. High prevalence of hepatitis a virus antibody among Bangladeshi children and young adults warrants preimmunization screening of antibody in HAV vaccination strategy. Indian J Med Microbiol 2009;27:48-50.

8. Tekkanat Tazegün Z, Yılmaz Y, Ülker Üstebay D, Üstebay S. Kars ili ve çevresinde 0-18 yaş arası çocuklarda Hepatit A seropozitifliği. Dicle Med J 2015;42:315-8.

9. Okur M, Erbey F, Acar MN, et al. Van ili ve çevresinde 0-18 yaşları arasındaki çocuklarda Hepatit A seropozitifliği. Düzce Tıp Dergisi 2011;13:6-9.

10. Aslan G, Seyrek A, İşçan A, et al. Şanlıurfa'da hepatit A seroprevalansı. Viral Hepatit J 2001;1:270-3.
11. Çiçek AÇ, Özkasap S, Dereci S, et al. Rize ilinde çocuk hastalarda hepatit A, B ve C seroprevalansı. Viral Hepat J 2012;18:102-6.

12 Güven F, Erkum AY, Erkum T, Say A. 0-15 yaş arası çocuklarda hepatit A seroprevalansı. Zeynep Kamil Tıp Bülteni 2004;35:41-4.

13 Aşcı Z, Akgün S, Keşli R, Demirtürk N. Afyonkarahisar ilinde farklı yaş gruplarında hepatit A seroprevalansı. Göztepe Tıp Dergisi 2014;29:94-8.

14 Kösecik M, Emiroğlu H, Tatlı M, et al. Şanlıurfa yöresinde çocuklarda asemptomatik hepatitis B virüs taşıyıcılığı prevalansı. Türk Pediatri Ars 1998:2;106-9.

15 Zeyrek CD, Zeyrek FY, İşcan A ve ark. Şanlıurfa'da çocuklarda hepatit a, b, c seroprevalansı. Viral Hepat J 2002;8:467-70.

16 Kaya A, Erbey MF, Okur M, et al. Hepatitis B virus seropositivity and vaccination for children aged $0-18$ in the Van region. J Pediatr Inf 2011;5:132-5.

17 Altan H, Demirtaş S, Taş D, Budakoğlu II. Ankara'da bir devlet hastanesine başvuran çocuklarda hepatit B seroprevalansının belirlenmesi. Ankara Med J 2017;1:1-8.

18 El-Shabrawi MH, Kamal NM. Burden of pediatric hepatitis C. World J Gastroenterol 2013;19:7880-8.

19. Köse \$̧, Ece G, Gözaydın A, Ergin Ö. İzmir Sosyal Hizmetler ve Çocuk Esirgeme Kurumuna (SHÇEK) bağlı yetiştirme yurtlarında yaşayan çocuklarda hepatit B ve hepatit C seroprevalansı. Viral Hepatit J 2010;16:64-8.

20. Atabek ME, Ural O, Çoban $\mathrm{H}$ ve ark. Konya yöresinde çocuklarda hepatit B ve C seroprevalansı. Genel Tıp Derg 2000;10:107-10. 